\title{
COMPETENCY ASSESSMENT OF THE FARMERS ON THE APPLICATION OF ONE HOUSE ONE FARM APPROACH
}

\author{
I. Islam1, M. J. Hoque ${ }^{2}$, M. A. Momen Miah ${ }^{3}$ and S. Sheheli2 \\ Department of Agricultural Extension Education, Bangladesh Agricultural University \\ Mymensingh-2202, Bangladesh
}

\begin{abstract}
The purposes of the study were to determine the extent of competency of the farmers on the application of One House One farm approach and to find out the relationships between the extent of competency of the farmers and their selected characteristics. Data were collected from 100 randomly selected farmers (out of 700) from two unions of Mymensingh Sadar Upazila. A pre-tested and structured interview schedule was used to collect data from the farmers during the period of 18 March to 01 April 2013. The extent of competency of the farmers on the application of One House One Farm approach was the dependent variable of the study. To measure the dependent variables, a total of 18 statements about competency of the farmers were selected and each of the competency was put against a four point rating scale such as excellent, above average, average and not at all, and the corresponding score were given as 3,2, 1, and 0, respectively. Therefore, the possible range of score of 20 competencies would be $0-54$. The competency gaps of the farmers were measured by Cut-Score method on rating scale. One hundred (100) is the Cut-Score with an assumption if all the respondents go for Average (score: 1). The independent variables, however, were measured by using suitable scales and techniques. Pearson's Product Moment Correlation Coefficient ( $\mathrm{r}$ ) was used to explore the relationships between the concerned variables. The findings indicate that majority of the respondents (94 per cent) had medium competency compared to 2 per cent of them having high competency. On the other hand, there were 4 respondents under low extent of competency. Out of ten selected characteristics, the farmer's level of education, farm size, training exposure, extension media contact, agricultural knowledge and awareness on One House One Farm approach showed significant positive relationships with their extent of competency on the application of One House One Farm approach. Age, household size, annual family income, and organizational participation had no relationships with their extent of competency on the application of One House One Farm approach.
\end{abstract}

Key Works: Competency assessment, One House One Farm approach, Farmer

${ }^{1}$ Former M.S. Student, ${ }^{2}$ Associate Professor and 3 Professor, Department of Agricultural Extension Education, Bangladesh Agricultural University, Mymensingh-2202, Bangladesh 


\section{INTRODUCTION}

Bangladesh is an agricultural based country. The development of Bangladesh depends largely on the development of agricultural sector. More than 149 million people live in this country with a density of 1,229.2 people per sq. $\mathrm{km}$ in 2010. The life expectancy in Bangladesh is only 66.80 years, and the adult literacy is also low, only 58.30 per cent. In the report of the UNDP Bangladesh placed 129th position in Human Development Index. However, the country having a very small economy in terms of GDP and per capita income. Agriculture is the backbone of the economy, which contributes 18.81 per cent of the GDP (BBS, 2010).

Most of the population in the country lives in rural areas and they depend on agriculture directly or indirectly for their livings. For their livelihoods, rural people depend on land, which is fertile but extremely vulnerable. Most of the country is made up of floodplain, and while the alluvial soil provides good arable land, large areas are at risk because of frequent floods and cyclones, which take lives and destroy crops, livestock and property. The over dependence on land and acute scarcity of land in the country are the main cause of poverty in the rural areas. A low estimate of 20 per cent of the rural poor is in chronic poverty. They suffer from persistent food insecurity, own no land and assets are often uneducated and may also suffer serious illnesses or disabilities. Another 29 per cent of the rural population is considered as moderately poor. Though they own a small plot of land and some livestock and generally have enough to eat; their diets lack nutritional values (BBS, 2010).

Nearly half of the rural households are landless. The 40 per cent poor people in the country own only 2 per cent of the total cultivable land of the country. Due to the emerging growth of population, the per cent of landless people are increasing. In rural areas, about 4.48 million households are landless. Another problem is arising due to urbanization. The number of absentee land owners is increasing in the rural areas. About $10 \%$ absentee land owners own $50.6 \%$ of the total cultivable land of Bangladesh (Ershad, 2010). The socioeconomic condition of the farmer is very poor. The farm families are the main contributor to the economy and also the major portion of the population. To develop the country, it is very important to develop the household situation of the farm families. The present government has taken steps for developing the poor rural communities. One House One Farm approach has been taken to develop the situation of the poor farm families and reduce the poverty level of the country. Because the major portion of the population in the country are poor. So, One House One Farm approach is very essential for the poor people to develop their present condition. The success of One House One Farm approach depends on the adoption and practice by the farmers. The adoption and practice of One House One Farm approach is required training. The training process begins with a sort of triggering event. The triggering event is the recognition of Organizational Performance Deficiency (OPD). When the Actual Organizational Performance (AOP) is less than Expected Organizational Performance (EOP), OPD exists. Once the performance deficiencies are identified, the causes must be identified then. If it is caused by inadequate Knowledge, Skills and Attitudes (KSAs), training becomes a way to satisfy the need. Performance deficiency that is caused by lack of motivation or equipments and unfavourable environment require different solutions to 
satisfy the need. The performance deficiencies to be addressed by training are given prioritization. Consequently, farmers require two levels of competence such as technical and managerial.

Technical competence is indicated when a farmer is able to select and combine profitable enterprises. An enterprise or combination of enterprises is profitable when the total receipts exceed total payments; allocate and utilize production factors efficiently. Production factors are efficiently allocated when the value of the marginal physical product is equal to the marginal factor cost. Efficiently utilized when the least possible amount of resources is used to obtain the best level of output; adopt and use modern production practices and techniques; identify activities, operations, materials, equipment and people needed to undertake the activities and operations; set time and cost targets and identify production risks. Managerial competence, on the other hand, should enable farmers to administer the farm effectively. A farmer is managerially competent if he is able to determine the rules and procedures of the organization determine the line of command or hierarchy of authority within the farm; recruit, train staff and allocate responsibilities; co-ordinate the production process i.e., meet production and supply schedules, cost and time targets and deal with government agencies and other firms such as input suppliers, credit and insurance providers, processors etc. The successful performance of the above entrepreneurial functions requires a certain level of knowledge, skills and attitudes acquired through training (formal and informal) and experience. So, for higher competency it is necessary to ensure better practice of One House One Farm approach by the farmers considering some relevant facts, those can influence the extent of competency of the farmers on the application of One House One Farm approach such as farmers socio-economic condition, their relationship with extent of competency of the farmers on the application of One House One Farm approach. In view of the foregoing discussion, the study aimed i) to determine the extent of competency of the farmers on the application of One House One Farm approach; ii) to find out the present competency gap of the farmers on the application of One House One Farm approach; iii) to determine the relationship between the extent of competency of farmers and their selected characteristics; and iv) to explore the problems encountered by the farmers on the application of One House One Farm approach.

\section{METHODOLOGY}

The study was conducted in two unions under Mymensingh Sadar Upazila, where One House One Farm farmers were available. Bhabkhali and Char Ishwardia unions were selected purposively as the study area. Updated lists of all the One House One Farm farmers were collected from the Deputy Director's (DD) office of the Bangladesh Rural Development Board (BRDB) in Mymensingh district. In Bhabkhali and Char Ishwardia union, 700 One House One Farm farmers were found from which 15 per cent were selected randomly. Therefore, a total of 105 farmers were selected as the sample of the study. In order to collect relevant data for the study, a structured interview schedule was carefully prepared during the period from 18 March to 01 April 2013.The researcher did not face any major problem in collecting data. At the end of data collection, the collected data were coded, compiled, tabulated and analyzed. The local units were converted into standard 
units. The qualitative data were transferred into quantitative data by appropriate scoring technique. Descriptive statistics such as range, frequency, number, per centages, mean, standard deviation and rank order were used for categorization and describing the variables. Analysis such as mean, range, number and percentage, standard deviation and rank order were used to explain the data. Pearson's Product Moment Correlation Coefficient (r) was used for testing the relationships between the concerned variables.

\section{Measurement of the farmers' competency on the application of one house one farm}

The extent of competency of the farmers on the application of One House One Farm approach was the dependent variable of the study. To measure the dependent variables, a total of 18 statements about competency of the farmers were selected and each of the competency was put against a four point rating scale such as excellent, above average, average and not at all and the corresponding score were given as 3, 2, 1, and 0, respectively. Therefore, the possible range of score of 20 competencies would be $0-54$. The competency gaps of the farmers were measured by Cut-Score method on rating scale. One hundred (100) is the Cut-Score with an assumption if all the respondents go for Average (score: 1).

\section{FINDINGS AND DISCUSSION}

\section{Farmers' competency on the application of one house one farm approach}

The combined calculated competency score of the farmers ranged from 21 to 35 against the possible score of 0 to 54 with an average score of 27.30 and standard deviation of 2.69. The farmers were categorized into three classes based on their competency scores; they are low competency, medium competency, and high competency. The distribution of the farmers according to the competency score has been shown in Table 1. Data in Table1 reveals that, $94 \%$ of the farmers had medium competency, $4 \%$ had low competency and $2 \%$ had high competency on the application of One House One Farm approach. In our country the farmers are used to monoculture (especially rice) so they are not aware of the integrated farming system. In case of some farmers, they were practicing One House One Farm approach but they were not aware of it. The government recently started the One House One Farm project. So it will take more time to get favorable competency of the farmers.

Table 1. Distribution of the farmers in terms of competency score $(n=100)$

\begin{tabular}{|c|c|c|c|c|c|c|}
\hline \multirow{2}{*}{$\begin{array}{c}\text { Possible } \\
\text { score }\end{array}$} & \multirow{2}{*}{$\begin{array}{l}\text { Observed } \\
\text { score }\end{array}$} & \multirow[t]{2}{*}{ Categories } & \multicolumn{2}{|c|}{ Farmer } & \multirow[t]{2}{*}{ Mean } & \multirow[t]{2}{*}{ SD } \\
\hline & & & No. & $\%$ & & \\
\hline \multirow[t]{4}{*}{$0-54$} & $21-35$ & Low competency $(<23)$ & 4 & 4 & 27.30 & 2.69 \\
\hline & & Medium competency (23-33) & 94 & 94 & & \\
\hline & & High competency $(<33)$ & 2 & 2 & & \\
\hline & & Total & 100 & 100 & & \\
\hline
\end{tabular}

*SD stands for standard deviation

In the contrast to this study, several other authors got different results in their studies in respect of competency. Azad (2000) conducted a study on job performance and job 
satisfaction of the Female Block Supervisors and only 3 per cent had high satisfaction. More than half (53 per cent) of the Female Block Supervisors had low job satisfaction compared to 44 per cent of them having medium satisfaction.

\section{Assessing competency gap through cut score method on likert scale}

Farmers' competency on the application of One House One Farm approach was investigated in this research. The extents of agreement against 18 statements as perceived by the farmers were assessed in this regard. The statements were arranged under three topics i.e. knowledge, skills and attitudes. Competency score for each statement was calculated by using the competency index $(\mathrm{CI})$. The mean score of each statement was also calculated. Competency index was found to vary from 41 to 280 . As 'average' has weight of 1 maximum score to declare gap is $100 \times 1=100$ for one variable. Thus, 100 is the cut score point. Thirteen variables showed in Table 2 are not showing any gap means that the respondents possess the competence attributes at an acceptable level and don't need much emphasis on training; therefore, these variables are excluded from the rest of the analysis.

Table 2. Statements relevant to farmers' competency with no gap

\begin{tabular}{lcccccc}
\hline \multicolumn{1}{c}{ Aspects } & Excellent & Above average & Average & Not at all & Total \\
\hline Weight & 3 & 2 & 1 & 0 & \\
\hline Knowledge & & & & & \\
1. Food security & $80(3)=240$ & $20(2)=40$ & 0 & 0 & 280 \\
2. Economic stability & $40(3)=120$ & $55(2)=110$ & $5(1)=5$ & 0 & 235 \\
3. Rural development & $24(3)=72$ & $70(2)=140$ & $6(1)=6$ & 0 & 218 \\
4. Social status & $10(3)=30$ & $57(2)=114$ & $33(1)=33$ & 0 & 177 \\
5. Improve basic needs & $12(3)=36$ & $58(2)=116$ & $30(1)=30$ & 0 & 182 \\
6. Protect environmental degradation & $1(3)=3$ & $55(2)=110$ & $44(1)=44$ & 0 & 157 \\
\hline Skills & & & & & \\
7. Personal relationship & 0 & $55(2)=110$ & $45(1)=45$ & 0 & 155 \\
8. Creation of unity & $3(3)=9$ & $57(2)=114$ & $40(1)=40$ & 0 & 163 \\
9. Conducting meeting & 0 & $19(2)=38$ & $63(1)=63$ & 0 & 101 \\
10. Communication ability & $2(3)=6$ & $60(2)=120$ & $37(1)=37$ & 0 & 163 \\
11. Farm management & 0 & $52(2)=104$ & $42(1)=42$ & 0 & 146 \\
\hline Attitudes & $1(3)=3$ & $8(2)=16$ & $87(1)=87$ & 0 & 106 \\
12. Social ecology & $8(3)=24$ & $75(2)=150$ & $17(1)=17$ & 0 & 191 \\
13. Team work & & & &
\end{tabular}

Data showed in Table 3 indicate the competency gap of farmers on the five variables such as skills in preparing family budget, punctuality, initiatives, leadership and socio-political activities. Thus, there is a need for training and other capacity building interventions for these aspects. 
Table 3. Statements relevant to farmers' competency with showing the gap

\begin{tabular}{lcccc|c|c}
\hline \multicolumn{1}{c}{ Aspects } & Excellent & Above average & Average & Not at all & Total \\
\hline $\begin{array}{l}\text { Weight } \\
\text { Skills }\end{array}$ & 3 & 2 & 1 & 0 & \\
$\begin{array}{l}\text { 1. Skills in preparing family budget } \\
\text { Attitudes }\end{array}$ & 0 & $17(2)=34$ & $63(1)=63$ & 0 & 97 \\
2. Punctuality & & & & & \\
3. Initiatives & 0 & $8(2)=16$ & $77(1)=77$ & 0 & 93 \\
4. Leadership skills & $1(3)=3$ & $8(2)=16$ & $83(1)=83$ & 0 & 99 \\
5. Socio-political activities & 0 & $5(2)=34$ & $60(1)=60$ & 0 & 97 \\
\hline
\end{tabular}

\section{Selected characteristics of the farmers}

The distributions of the farmers according to their selected characteristics have been shown in the Table 4 . The findings indicate that the highest proportion $(49 \%)$ of the farmers was in the young aged category compared to $35 \%$ middle aged and $16 \%$ old age category. The young and middle aged farmers constituted about $84 \%$ of the farmers. An overwhelming the large proportion (56 per cent) of the farmers fell under category of "Secondary education" compared to 35 per cent with primary education, 2 per cent having above secondary education and 7 per cent could "Can sign only". Majority of the farmers (48\%) had medium sized household, 38\% had small and 14\% had large household. The highest proportion (95\%) of the respondents possessed the marginal category compared to $5 \%$ landless farmers. The highest proportion $(64 \%)$ of the farmers had lower annual family income compared to $23 \%$ medium and $13 \%$ higher annual family income. The highest proportion $(87 \%)$ of the farmers had short-term training compared to $10 \%$ midterm and $3 \%$ long term training exposure.

The highest proportion $(100 \%)$ of the farmers had low organizational participation and no farmer was found under low organizational participation. The highest proportion (79 per cent) of the respondents had low extension media contact while 21 per cent had medium extension media contact and no farmer was found under high extension media contact. Majority $(99 \%)$ of the farmers had high agricultural knowledge, 1\% had medium agricultural knowledge and no farmer was found under low agricultural knowledge. Majority $(63 \%)$ of the farmers had high awareness, $37 \%$ had moderate awareness and no farmers were found with low awareness.

Relationship between the selected characteristics of the farmers and their competency on the application of one house one farm approach

The purpose of this section is to determine the relationships between the selected characteristics of the farmers and their extent of competency of One House One Farm approach. The characteristics included age, education, household size, farm size, annual family income, training exposure, extension media contact, organizational participation, agricultural knowledge and awareness of the farmers on One House One Farm approach. Each of the characteristics constituted an independent variable, while the extent of 
competency of the farmers on One House One Farm approach was the dependent variable in this study. Data in Table 5 reveal that level of education, farm size, training exposure, extension media contact, agricultural knowledge and awareness of the farmers on the application of One House One Farm approach had significant positive relationships with their competency.

Table 4. Salient features of the selected characteristics of farmers

\begin{tabular}{|c|c|c|c|c|c|c|c|}
\hline \multirow[t]{2}{*}{ Characteristics } & \multirow{2}{*}{$\begin{array}{l}\text { Scoring } \\
\text { system }\end{array}$} & \multirow{2}{*}{$\begin{array}{c}\text { Range } \\
\begin{array}{l}\text { Observed } \\
\text { (possible) }\end{array}\end{array}$} & \multirow[t]{2}{*}{ Categories } & \multicolumn{2}{|c|}{ Respondent } & \multirow[t]{2}{*}{ Mean } & \multirow[t]{2}{*}{$\mathrm{SD}^{*}$} \\
\hline & & & & $\begin{array}{l}\text { Number } \\
(\mathrm{n}=100)\end{array}$ & $\begin{array}{c}\text { Per cent } \\
(\%)\end{array}$ & & \\
\hline \multirow[t]{3}{*}{ Age } & \multirow{3}{*}{$\begin{array}{l}\text { Actual } \\
\text { years }\end{array}$} & \multirow{3}{*}{$\begin{array}{c}22-65 \\
\text { (Unknown) }\end{array}$} & Young (up to 35) & 49 & 49 & \multirow[t]{3}{*}{38.58} & \multirow[t]{3}{*}{11.12} \\
\hline & & & Middle age (36-50) & 35 & 35 & & \\
\hline & & & Old $(>50)$ & 16 & 16 & & \\
\hline \multirow{4}{*}{$\begin{array}{l}\text { Level of } \\
\text { education }\end{array}$} & \multirow{4}{*}{$\begin{array}{c}\text { Years of } \\
\text { schooling }\end{array}$} & \multirow{4}{*}{$\begin{array}{c}0.5-12 \\
\text { (Unknown) }\end{array}$} & Can sign only (0.5) & 7 & 7 & \multirow[t]{4}{*}{5.98} & \multirow[t]{4}{*}{2.60} \\
\hline & & & Primary (1-5) & 35 & 35 & & \\
\hline & & & Secondary (6-10) & 56 & 56 & & \\
\hline & & & Above secondary $(>10)$ & 2 & 2 & & \\
\hline \multirow[t]{3}{*}{ Household size } & \multirow{3}{*}{$\begin{array}{c}\text { No. of } \\
\text { members }\end{array}$} & \multirow{3}{*}{$\begin{array}{c}2-18 \\
\text { (Unknown) }\end{array}$} & Small (2-4) & 38 & 38 & \multirow[t]{3}{*}{5.08} & \multirow[t]{3}{*}{2.10} \\
\hline & & & Medium (5-6) & 48 & 48 & & \\
\hline & & & Large $(>6)$ & 14 & 14 & & \\
\hline \multirow[t]{2}{*}{ Farm size } & \multirow[t]{2}{*}{ Hectares } & $0.01-0.12$ & Landless ( 0.03$)$ & 5 & 5 & \multirow[t]{2}{*}{0.07} & \multirow[t]{2}{*}{0.02} \\
\hline & & (Unknown) & Marginal $(0.03)$ & 95 & 95 & & \\
\hline \multirow{3}{*}{$\begin{array}{l}\text { Annual family } \\
\text { income }\end{array}$} & \multirow[t]{3}{*}{$\begin{array}{ll}000 & \text { TK }\end{array}$} & $9-340$ & Low $(<60)$ & 64 & 64 & \multirow[t]{3}{*}{63.84} & 60.07 \\
\hline & & (Unknown) & Medium (61-100) & 23 & 23 & & \\
\hline & & & Large $(>100)$ & 13 & 13 & & \\
\hline Training & Days & $0-28$ & Short term $(<4)$ & 87 & 87 & 2.18 & 3.82 \\
\hline exposure & & (Unknown) & Midterm (4-7) & 10 & 10 & & \\
\hline & & & Long-term (>7) & 3 & 3 & & \\
\hline Organizational & Score & $1-6$ & Low $(<10)$ & 100 & 100 & 1.67 & 0.85 \\
\hline participation & & $(1-30)$ & Medium (10-20) & 00 & 00 & & \\
\hline Extension media & Score & $6-19$ & Low $(<13)$ & 79 & 79 & 9.82 & 3.46 \\
\hline contact & & $(0-39)$ & Medium (13-26) & 21 & 21 & & \\
\hline & & & High $(>26)$ & 0 & 0 & & \\
\hline Agricultural & Score & $20-29$ & Low $(<10)$ & 0 & 0 & 24.87 & 1.83 \\
\hline knowledge & & $(0-30)$ & Medium (10-20) & 1 & 1 & & \\
\hline & & & High $(>20)$ & 99 & 99 & & \\
\hline Awareness of & Score & $16-27$ & Low $(<11)$ & 0 & 0 & 22.83 & 1.72 \\
\hline the farmers on & & $(0-33)$ & Medium (11-22) & 37 & 37 & & \\
\hline One House One & & & High $(>22)$ & 63 & 63 & & \\
\hline Farm approach & & & & & & & \\
\hline
\end{tabular}

The farmers having better education were interested to follow One House One Farm approach and improve their livelihood. Large farmers can easily adopt One House One Farm approach. Farmers can increase their competency on the application of one house one farm approach through participating different trainings and getting more exposure to extension media contact. Biswas (2009), Roy (2009) and Alam (2008) found the similar findings in their respective studies. On the other hand, household size, annual family 
income and organizational participation had positive relationships with their competency. But age had negative relationship with their competency.

Table 5. Coefficient of correlation (r) between the selected characteristics of the farmers and their competency $(n=100)$

\begin{tabular}{|c|c|c|c|c|}
\hline \multirow[t]{2}{*}{ Focus variables } & \multirow[t]{2}{*}{ Characteristics of the farmers } & \multirow{2}{*}{$\begin{array}{l}\text { Coefficient of } \\
\text { correlation }(\mathrm{r}) \\
\text { values }\end{array}$} & \multicolumn{2}{|c|}{ Tabulated r value with $98 \mathrm{df}$} \\
\hline & & & 0.05 level & 0.01 level \\
\hline \multirow{10}{*}{$\begin{array}{l}\text { Competency } \\
\text { assessment of } \\
\text { the farmers on } \\
\text { the application } \\
\text { of One House } \\
\text { One Farm } \\
\text { approach }\end{array}$} & Age & -0.048 & 0.197 & 0.257 \\
\hline & Level of education & $0.579^{* *}$ & & \\
\hline & Household size & 0.083 & & \\
\hline & Farm size & $0.709^{* *}$ & & \\
\hline & Annual family income & 0.106 & & \\
\hline & Training exposure & $0.320^{* *}$ & & \\
\hline & Organizational participation & 0.189 & & \\
\hline & Extension media contact & $0.204^{*}$ & & \\
\hline & Agricultural knowledge & $0.843^{* *}$ & & \\
\hline & $\begin{array}{l}\text { Awareness of the farmers on the } \\
\text { application of One House One Farm } \\
\text { approach }\end{array}$ & $0.216^{*}$ & & \\
\hline
\end{tabular}

\section{Problem confrontation by the farmers in one house one farm approach}

The problem confrontation score of the farmers ranged from 19 to 29 against the possible range of 0 to 36 with as average of 24.07 and standard deviation of 1.98. The table revealed that majority of the farmers (47 per cent) faced high problems in adopting One House One Farm Approach. Only 53 per cent faced moderate problems and none of the farmers faced under low problems. Similar results were found by Alam (2008) and Roy (2009).

Table 6. Distribution of farmers according to their problems in adopting One House One Farm approach $(\mathrm{n}=100)$

\begin{tabular}{|c|c|c|c|c|c|c|}
\hline \multirow{2}{*}{$\begin{array}{c}\text { Possible } \\
\text { score }\end{array}$} & \multirow{2}{*}{$\begin{array}{c}\text { Observed } \\
\text { score }\end{array}$} & \multirow[t]{2}{*}{ Categories } & \multicolumn{2}{|c|}{ Farmer } & \multirow[t]{2}{*}{ Mean } & \multirow[t]{2}{*}{ SD } \\
\hline & & & No. & $\%$ & & \\
\hline \multirow[t]{4}{*}{$0-36$} & $19-29$ & Low $(<12)$ & 0 & 0 & 24.07 & 1.98 \\
\hline & & Moderate (12-24) & 53 & 53 & & \\
\hline & & High $(<24)$ & 47 & 47 & & \\
\hline & & Total & 100 & 100 & & \\
\hline
\end{tabular}

It was found that 'Lack of knowledge on mixed farming' got the highest score and hence was considered as the $1^{\text {st }}$ ranked problem. In our country, most of the population does not get appropriate training due to their poverty. When the poor farmers don't get support from the implementing agency then the project will not be successful. 'Complex loan 
distributing processes' got the second highest score and hence was considered as the $2^{\text {nd }}$ ranked problem. This is due to the complex and lengthy loan distribution systems of our country. The problem 'Less technical support from different organizations' got the third highest score and hence was considered as $3^{\text {rd }}$ ranked position.

\section{CONCLUSIONS}

The study reveals that majority of the farmers' had moderate or less competency on the application of One House One Farm approach. This led to the conclusion that for the better adoption of this approach among the farmer high competencies is required. The findings indicate that the highest proportion $(49 \%)$ of the farmers was in the young aged category. Age of the fish farmers had significant negative relationship with their extent of competency of One House One Farm approach. So, it can be concluded that the extent of competency of One House One Farm approach of the farmers gradually decrease with the increase of their age. The statistical analysis showed significant positive relationship of level of education, farm size, training exposure, extension media contact, agricultural knowledge and awareness of the farmers on the application of One House One Farm approach had significant positive relationships with their competency. Therefore, it may be concluded that these characteristics of the farmers can play an important role to improve their extent of competency of One House One Farm approach. Farmers fell many gaps to manage the One House One Farm approach. Among these gaps, the most important are preparing family budget, punctuality, initiatives, leadership skills and socio political activism. In some cases, they get training but no credit facilities and some farmers get credit and technical support without training or untimely training. Farmers face many problems to get technical support and credit from the government. In some cases, they get training but no credit facilities and some farmers get credit and technical support without training or untimely training. The loan distribution system seems to very much complex to the farmers.

\section{REFERENCES}

Alam, M. N. 2008. Farmers' Perception of Rural Women in Homestead Management Towards Integrated Plant Nutrient System. M. S. Thesis. Department of Agricultural Extension Education, Bangladesh Agricultural University, Mymensingh, Bangladesh.

Azad, A. K. 2000. Job Performance and Job Satisfaction of the Female Block Supervisors Under Dhaka and Mymensingh Agricultural Regions. M.S. Thesis. Department of Agricultural Extension Education, Bangladesh Agricultural University, Mymensingh, Bangladesh.

BBS. 2010. Statistical Yearbook of Bangladesh. Bangladesh Bureau of Statistics, Statistical Division. Ministry of Planning. Government of the People's Republic of Bangladesh.

Biswas, M. 2009. Rural Women's Perception of Prospect of Scavenging Chicken Rearing. M.S. Thesis. Department of Agricultural Extension Education, Bangladesh Agricultural University, Mymensingh, Bangladesh.

Ershad, A. 2002. Analysis of Poverty Dynamics: Bangladesh Perspective. Journal of third World Studies.

Roy, B. S. 2009. Farmers' Perception of the Effect of IPM for Sustainable Crop Production. M.S. Thesis. Department of Agricultural Extension Education, Bangladesh Agricultural University, Mymensingh, Bangladesh. 


\section{Corrigendum}

Vol. 22, Number 1 \& 2, January-December 2011: Efficacy of malathion for controlling red pumpkin beetle, Aulacophora foveicollis (Lucas) in

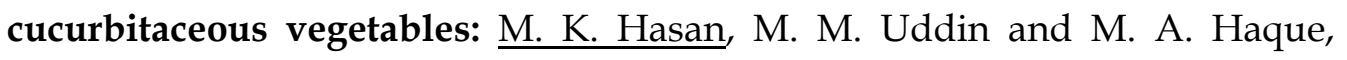
should be read as:

Vol. 22, Number 1 \& 2, January-December 2011: Efficacy of malathion for controlling red pumpkin beetle, Aulacophora foveicollis (Lucas) in cucurbitaceous vegetables: $\underline{\text { K. Hassan, }}$ M. M. Uddin and M. A. Haque 